\title{
A Novel Conducting Nanocomposite Obtained by p-Anisidine and Aniline With Titanium(IV) Oxide Nanoparticles: Synthesis, Characterization, and Electrochemical Properties
}

\author{
AQ4 AQ1 F. Chouli, ${ }^{1}$ I. Radja, ${ }^{1}$ E. Morallon, ${ }^{2}$ A. Benyoucef ${ }^{1}$ \\ ${ }^{1}$ Laboratoire De Chimie Organique, Macromoléculaire Et Des Matériaux, Université De Mascara., Bp 763, \\ Mascara 29000, Algeria
}

$\overline{\bar{\Sigma}}$

${ }^{2}$ Departamento De Química Física E Instituto Universitario De Materiales, Universidad De Alicante, Apartado 99, Alicante, E-03080, Spain

\begin{abstract}
Nanocomposites were successfully synthesized by the oxidative polymerization of $p$-anisidine and/or aniline monomers (at initial "p-anisidine:aniline" mole ratios of "100: 0", $50: 50$ ", and "0 : 100") with titanium(IV) oxide nanoparticles, in the presence of hydrochloric acid as a dopant with ammonium persulfate as an oxidant. The morphological, structural, conductivity, and electrochemical properties of the synthesized nanocomposites were studied using Transmission Electron Microscopy, X-ray diffraction, Fourier transform infrared spectroscopy, and UV-vis spectroscopies. The presence of polymer on $\mathrm{TiO}_{2}$ nanoparticles in samples nanocomposites was confirmed by the Transmission Electron Microscopy coupled with Energy Dispersive X-ray Spectroscopy. The thermal stability of samples nanocomposites were evaluated using the Thermogravimetric Analysis. Electrical conductivity of nanocomposites obtained is in the range of $0.08-0.91 \mathrm{~S} \mathrm{~cm}^{-1}$. The electrochemical behavior of the polymers extracted from the nanocomposites has been analyzed by cyclic voltammetry. Good electrochemical response has been observed for polymer films; the observed redox processes indicate that the polymerization on $\mathrm{TiO}_{2}$ nanoparticles produces electroactive polymers. These composite microspheres can potentially be used in commercial applications as fillers for antistatic and anticorrosion coatings. POLYM. COMPOS., 00:000-000, 2015. (C) 2015 Society of Plastics Engineers
\end{abstract}

Correspondence to: A. Benyoucef; e-mail: ghani29000@yahoo.fr Contract grant sponsor: National Assessment and Planning Committee of the University Research (CNEPRU); contract grant number: E-03720130015; contract grant sponsor: MINECO; contract grant number: MAT2013-42007-P; contract grant sponsor: Generalitat Valenciana; contract grant number: PROMETEO2013/038; contract grant sponsor: Directorate General of Scientific Research and Technological Development (DGRSDT) of Algeria.

DOI 10.1002/pc.23837

Published online in Wiley Online Library (wileyonlinelibrary.com).

(C) 2015 Society of Plastics Engineers

\section{INTRODUCTION}

Titania is of tremendous interest for applications in photovoltaic devices such as solar cells [1,2] photo-catalysis [3], and photo-electrochemistry [4]. For example, titania is a key component of the dye-sensitized solar cell (DSSC). $\mathrm{TiO}_{2}$ is used to transport electrons from the light absorbing layer (such as $\mathrm{Ru}(\mathrm{dcbpy})_{2}(\mathrm{NCS})_{2}$ dye) to the current collector. Recently, there has been tremendous interest in the use of nanocrystalline titania and mesoporous networks of titania in both DSSCs utilizing liquid electrolytes as well as solid-state solar cells [5]. Mesoporous titania networks are extensively used to investigate performance of solar cells, particularly the Grätzel cell designs [6], and several approaches have been developed to fabricate nanostructured titania [5]. Nanotubes of titania have also attracted attention owing to their potential for application in photovoltaic devices [7].

In recent years, the organic/inorganic nanocomposites with an organized structure are receiving growing attention, since they usually provide a new functional hybrid with synergetic or complementary behavior between organic and inorganic materials. One of the most promising composites system are the hybrids based on conducting polymers and metallic oxides in industrial and academic fields such as toners in photocopying, rechargeable batteries, sensors, drug delivery etc. [8]. These nanocomposite materials are especially important due to their bridging role between the world of conducting polymers and that of inorganic materials. Though inorganic semiconductors, such as $\mathrm{SnO}_{2}$ [9], $\mathrm{Fe}_{2} \mathrm{O}_{3}$ [10], $\mathrm{V}_{2} \mathrm{O}_{5}$ [11], $\mathrm{WO}_{3}$ [12]. Hence, combining these two kinds of materials to form composite may lead to a synergy effect and help to enhance each other, which are helpful for improving sensor properties such as thermal stability, lower operating temperature and fast response and recovery. 
Nevertheless, the practical use of polyaniline has been limited due to its insolubility in common organic solvents and infusibility, resulting in poor processability. Efforts have been made to improve the processability of polyaniline by using appropriate functionalized protonic acids or substituted polyaniline [13]. In the latter approach, a suitable substituent is attached either at the nitrogen atom or in the phenyl ring of the repeat units. Among the substituted polyaniline derivatives, poly(o-anisidine) (POA) is a polyaniline with a methoxy $\left(-\mathrm{OCH}_{3}\right)$ group in the chain. Composite material that has been prepared by POA may be more interesting as the behavior of the organicinorganic composite material can be employed as an electrochemical supercapacitor [12]. Patil et al. [9, 14] synthesized conducting polymer- $\mathrm{WO}_{3}$ and poly(o-anisidine)$\mathrm{SnO}_{2}$ composites and evaluated their performances as sensing materials in the fabrication of humidity sensors and they demonstrated that a simple mechanical mixing of the organic and inorganic materials significantly improved their humidity sensing characteristics.

A novel $\mathrm{POA} / \mathrm{CoFe}_{2} \mathrm{O}_{4}$ nanocomposite was synthesized by a facile in situ polymerization of o-anisidine in the presence of $\mathrm{CoFe}_{2} \mathrm{O}_{4}$ nanoparticles [13]. $\mathrm{POA} / \mathrm{SnO}_{2}$ nanocomposites were also synthesized through an in situ chemical polymerization of o-anisidine $(\mathrm{OA})$ in the presence of $\mathrm{SnO}_{2}$ nanoparticles of $25-40 \mathrm{~nm}$ in diameter [15]. POA was prepared through chemical oxidation polymerization, and the nanocomposite of this polymer was prepared with different metals oxide nanoparticles [16]. $\mathrm{POA} / \mathrm{TiO}_{2}$ composite microspheres were synthesized in the presence of salicylic acid (SA) as a dopant with ammonium persulfate as an oxidant. $\mathrm{POA}-\mathrm{SA} / \mathrm{TiO}_{2}$ composites thus obtained exhibited regular spherical morphology a conductivity of $8.72 \times 10^{-4} \mathrm{~S} \mathrm{~cm}^{-1}$ was obtained for composites microspheres containing $24.5 \%$ POA [17].

In this work the synthesis of nanocomposite of $\mathrm{TiO}_{2}$ nanoparticles and poly(p-anisidine) (PPA) by using an in situ chemical polymerization route has been studied. The p-anisidine (PA) is a substituted derivative of aniline with the methoxy $\left(-\mathrm{OCH}_{3}\right)$ group in para position. The PPA was chosen as an organic counterpart for this study to explore the possibility of utilizing it as an alternative to PANI for technological application. To the best of our knowledge, very few reports can befound in the literature on the synthesis of polyanisidine- $\mathrm{TiO}_{2}$ nanocomposites and the investigation of their characteristics and conducting properties.

\section{EXPERIMENTAL}

\section{Materials}

The monomers aniline (ANI) (from Aldrich) was distilled under vacuum prior to use and p-anisidine (PA) (from Aldrich) was used as received. Perchloric acid and hydrochloric acid (from Merck) was suprapur quality and all the solutions were freshly prepared with distilled-

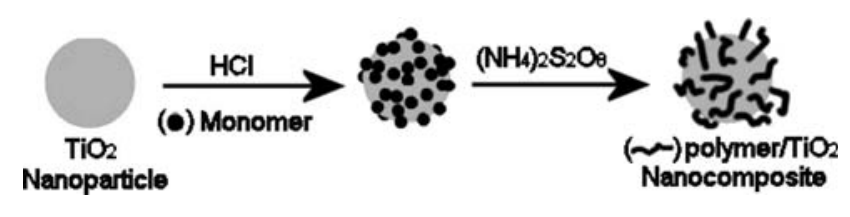

FIG. 1. The polymerization procedures for polymer/ $/ \mathrm{TiO}_{2}$ nanocomposites.

deionized water was obtained from an Elga Labwater Purelab Ultra system. A titanium(IV) oxide $\left(\mathrm{TiO}_{2}\right)(99 \%)$ is purchased from the Sigma-Aldrich Company. Ammonium persulfate $\left(\left(\mathrm{NH}_{4}\right)_{2} \mathrm{~S}_{2} \mathrm{O}_{8}\right)$ and ammonia solution $\left(\mathrm{NH}_{4} \mathrm{OH}\right)$ were all of analytical purity and used without further purification.

\section{Chemical Synthesis of Nanocomposites}

The preparation of $\mathrm{PPA} / \mathrm{TiO}_{2}$ nanocomposite can be summarized as follows: the $\mathrm{TiO}_{2}$ nanoparticle sample was dried at $110^{\circ} \mathrm{C}$ for $1 \mathrm{~h}$, and then $1.0 \mathrm{~g}$ of the dried sample was added to $30 \mathrm{~mL}$ of $1 \mathrm{M} \mathrm{HCl}$ solution containing $1.35 \mathrm{~g}$ of p-anisidine monomer and stirred for $1 \mathrm{~h}$. Then $2.51 \mathrm{~g}$ of ammonium persulfate in $20 \mathrm{~mL}$ of $1 \mathrm{M} \mathrm{HCl}$ solution was slowly added dropwise to the suspension mixture (using 1:1 monomer/oxidant mole ratio), and the solution was stirred at room temperature for $24 \mathrm{~h}$. The final products were bathed using $50 \mathrm{~mL}$ of $1 \mathrm{M} \mathrm{NH}_{4} \mathrm{OH}$ at room temperature while magnetically stirring for $2 \mathrm{~h}$. The product was collected by filtering and washing the precipitate with deionized water, and dried under vacuum at $60^{\circ} \mathrm{C}$ for $24 \mathrm{~h}[18,19]$.

The polymerization procedures for $\mathrm{PPA} / \mathrm{TiO}_{2}$ nanocomposite are shown in Fig. 1. using the procedure described in [20]. Since the surface charge of the metal oxide is positive in acidic conditions, an amount of $\mathrm{Cl}^{-}$ is adsorbed on the nanopowder surface to compensate the positive charges. In the same acidic conditions the PA monomers are converted to cationic anilinium ions, this leads to the electrostatic interactions produced between the adsorbed anions and cationic anilinium ions.

For comparison purposes, the PANI/TiO ${ }_{2}$, poly(PA-co$\mathrm{ANI} / \mathrm{TiO}_{2}$ nanocomposites and the homopolymer PPA (without $\mathrm{TiO}_{2}$ ) was synthesized under the same conditions.

\section{Nanocomposite Characterization}

The X-ray diffraction of the powder nanocomposites were obtained using a Bruker CCD-Apex equipment with a X-ray generator $(\mathrm{Cu} \mathrm{Ka}$ and $\mathrm{Ni}$ filter) operated at $40 \mathrm{kV}$ and 40mA. A Hitachi U-3000 spectrophotometer was used for recording the UV-Vis spectra. The homopolymers and co-polymers were dissolved in N-methyl-2-pyrrolidone (NMP). Fourier transform infrared (FT-IR) spectroscopy was recorded using a Bruker Alpha in $\mathrm{KBr}$ transmission mode. 


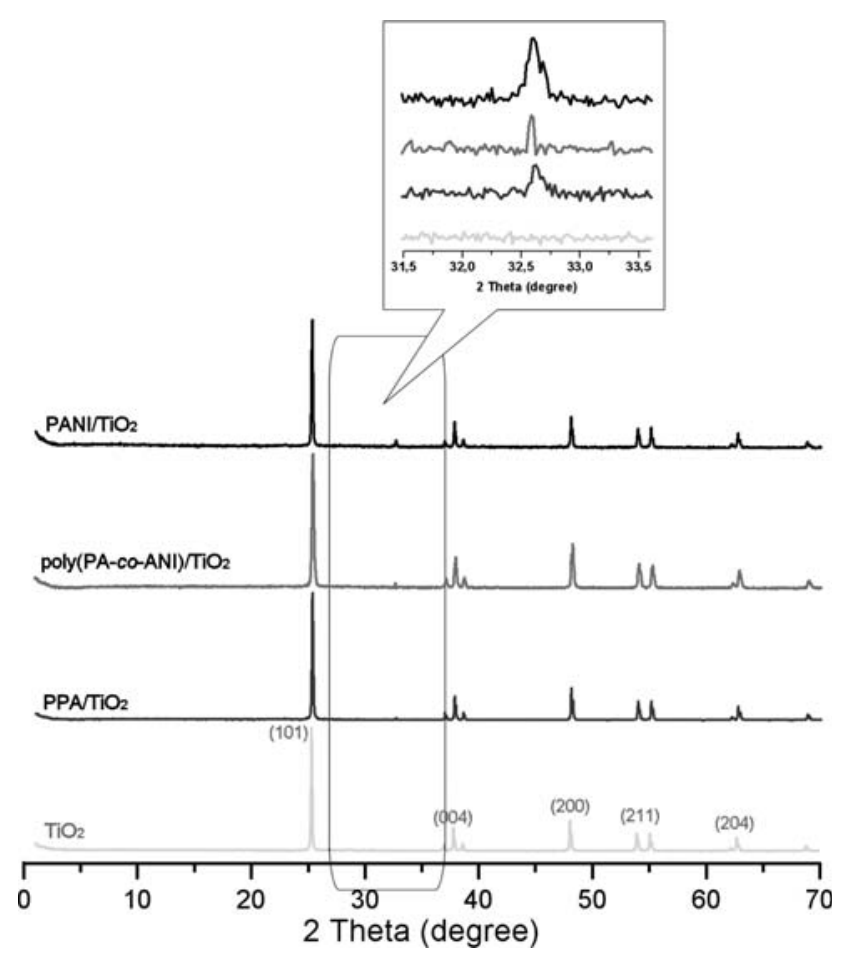

FIG. 2. XRD diffraction patterns of PPA/TiO ${ }_{2}$, poly $(\mathrm{PA}-\mathrm{co}-\mathrm{ANI}) / \mathrm{TiO}_{2}$, $\mathrm{PANI} / \mathrm{TiO}_{2}$ nanocomposites, and $\mathrm{TiO}_{2}$ nanoparticule. [Color figure can AQ3

be viewed in the online issue, which is available at wileyonlinelibrary. com.]

For Transmission Electron Microscopy (TEM) observations, the samples were dispersed in ethanol and supported on TEM grids. The images were collected using a JEOL (JEM-2010) microscope, working at an operation voltage of $200 \mathrm{kV}$. The TEM is coupled with Energy Dispersive X-ray Spectroscopy (EDS) for the elucidation of chemical composition of the samples.

The thermogravimetric analysis (TGA) was performed with a Du Pont thermogravimetric analyzer at a heating rate of $20^{\circ} \mathrm{C} / \mathrm{min}$ under nitrogen or air atmosphere. About $10 \mathrm{mg}$ of sample was heated to $900^{\circ} \mathrm{C}$.

\section{Electrochemical Characterization}

The electrochemical behavior of the polymers was studied by cyclic voltammetry after their extraction from the composite by dissolving in the N-methyl-2-pyrrolidone (NMP). It is known that this kind of conducting polymers is soluble in NMP [21], while the $\mathrm{TiO}_{2}$ remains in solid state. Thus, both components can be separated by filtration. Then the polymer films were obtained by casting a drop of these solutions over a working glassy carbon electrode $\left(0.07 \mathrm{~cm}^{2}\right.$ of geometrical area) and heating with an infrared lamp to remove the solvent. The electrochemical measurements were carried out using a conventional cell of three electrodes. The counter and reference electrodes were a platinum foil and a hydrogen reversible electrode (RHE) immersed in the supporting electrolyte, respectively. The electrolyte used was $1 \mathrm{M} \mathrm{HClO}_{4}$ and all experiments were carried out at $50 \mathrm{mV} . \mathrm{s}^{-1}$.

\section{Electrical Conductivity Measurements}

Electrical conductivity measurements were carried out using a Lucas Lab resistivity equipment with four probes in-line. The samples were dried in vacuum during $24 \mathrm{~h}$ and pellets of $0.013 \mathrm{~m}$ diameter were prepared using a FTIR mold by applying a pressure of $7.410^{8} \mathrm{~Pa}$.

\section{RESULTS AND DISCUSSION}

\section{X-Ray Diffraction Characterization}

Figure 2 shows the XRD pattern of $\mathrm{TiO}_{2}$ nanoparticles and polymer $/ \mathrm{TiO}_{2}$ nanocomposites $\left(\mathrm{PPA} / \mathrm{TiO}_{2}\right.$, poly(PAco-ANI) $/ \mathrm{TiO}_{2}$ and $\mathrm{PANI} / \mathrm{TiO}_{2}$ ). It can be seen that the $\mathrm{XRD}$ pattern of nanocomposites is more or less similar to that of $\mathrm{TiO}_{2}$ nanopartices. In all samples, it can be observed all the diffraction peaks of $\mathrm{TiO}_{2}$ that corresponds to anatase crystalline phase [22]. Hence, the polymers do not change the structure of $\mathrm{TiO}_{2}$.

In the XRD pattern of polymer/ $\mathrm{TiO}_{2}$ nanocomposites (Fig. 2) the peak of $\mathrm{TiO}_{2}$ at around $25^{\circ}$ is so intense that the characteristic peaks of polyaniline and poly(PA-coANI) cannot be observed. Also, it should be considered that the layer of polymer chains adsorbed on the surface of $\mathrm{TiO}_{2}$ is, most probably, less than $1 \mathrm{~nm}$ thick. In the composites a peak around $32^{\circ}$ is observed that can be associated to the polymers.

These observations were also observed by other authors with $\mathrm{TiO}_{2}$ /polyaniline composites [22-24].

The average crystallite sizes of $\mathrm{TiO}_{2}$ nanoparticles, and the three samples of nanocomposites were estimated from the X-ray diffraction patterns using Scherrer formula [25]:

$$
d=\frac{k \cdot \lambda}{\beta \cdot \cos \theta}
$$

where $d$ is the average crystallite size, $\lambda$ is the X-ray wavelength, $\beta$ is the full-width at half-maximum and $\theta$ is the diffraction angle. The value of $k$ depends on several factors, including the Miller index of reflection plane and the shape of the crystal. If shape is unknown, $k$ is often assigned a value of 0.9 . So the crystallite size of $\mathrm{TiO}_{2}$ nanoparticle, and the nanocomposites was computed from XRD patterns see Table 1 .

TABLE 1. The average crystallite size of the $\mathrm{TiO}_{2}$ nanoparticle and the three nanocomposites was computed from Scherrer formula.

\begin{tabular}{ccccc}
\hline Samples & $\mathrm{TiO}_{2}$ & $\mathrm{PPA} / \mathrm{TiO}_{2}$ & poly$(\mathrm{PA}-$ co-ANI/TiO & $\mathrm{PANI}_{2} / \mathrm{TiO}_{2}$ \\
\hline$d(\mathrm{~nm})$ & 30.80 & 46.64 & 31.73 & 42.45 \\
\hline
\end{tabular}




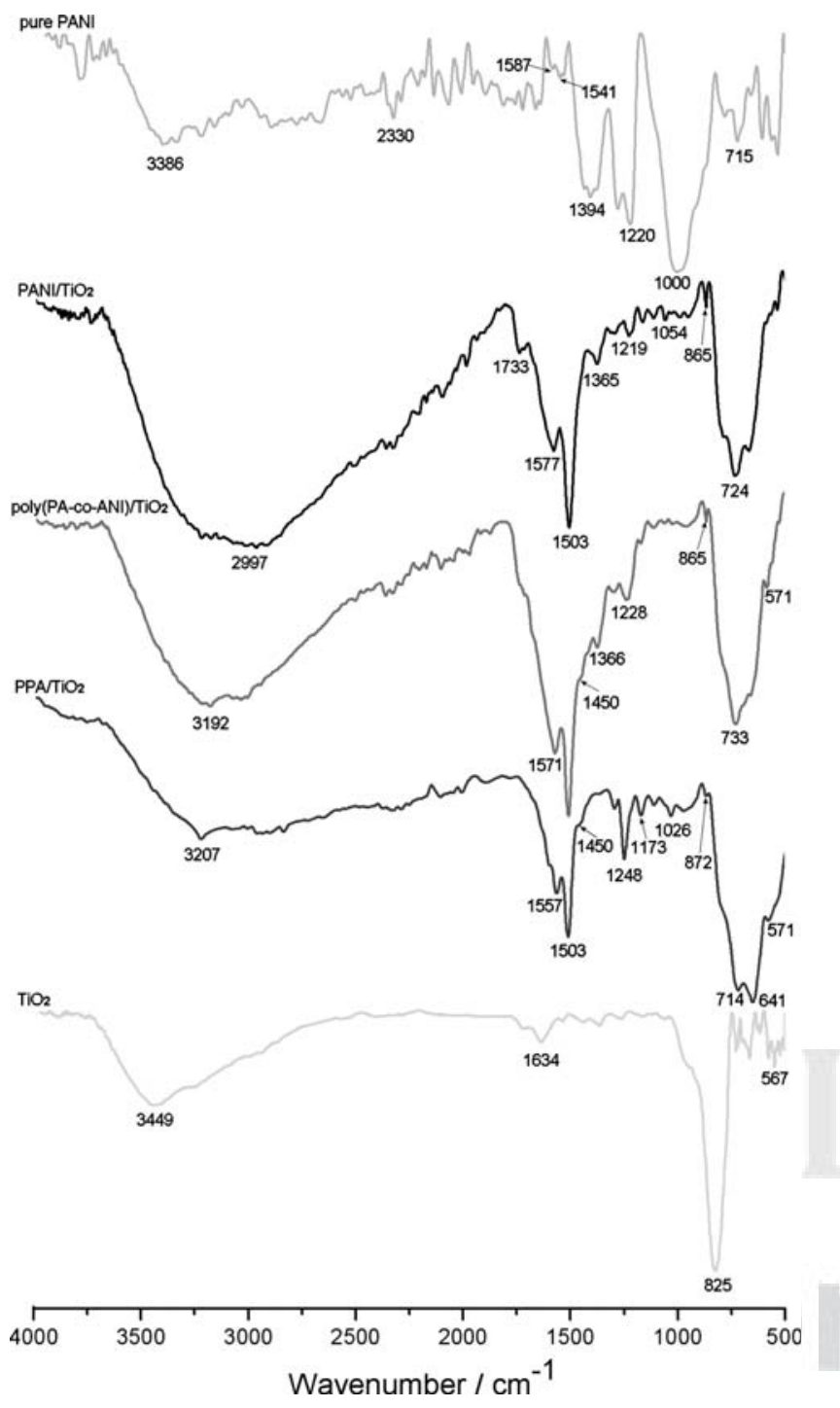

FIG. 3. FT-IR adsorption spectra of $\mathrm{PPA} / \mathrm{TiO}_{2}$, poly(PA-co-ANI)/TiO $\mathrm{PANI} / \mathrm{TiO}_{2}$ nanocomposites, pure PANI, and $\mathrm{TiO}_{2}$ nanoparticule. [Color figure can be viewed in the online issue, which is available at wileyonlinelibrary.com.

\section{Fourier-Transform Infrared Spectra}

Figure 3 shows the FTIR spectra of $\mathrm{TiO}_{2}$ nanoparticle, $\mathrm{PPA} / \mathrm{TiO}_{2}$, poly $(\mathrm{PA}-\mathrm{co}-\mathrm{ANI}) / \mathrm{TiO}_{2}, \mathrm{PANI} / \mathrm{TiO}_{2}$ and doped polyaniline.

The main characteristic bands of doped polyaniline are assigned as follows: the band at $3,386 \mathrm{~cm}^{-1}$ is attributable to $\mathrm{N}-\mathrm{H}$ stretching mode, $\mathrm{C}=\mathrm{N}$ and $\mathrm{C}=\mathrm{C}$ stretching mode for the quinoid and benzenoid rings occur at 1,587 and $1,541 \mathrm{~cm}^{-1}$, the bands at about 1,394 and $1,220 \mathrm{~cm}^{-1}$ have been attributed to $\mathrm{C}-\mathrm{N}$ stretching mode for benzenoid ring, while the peak at $1000 \mathrm{~cm}^{-1}$ is assigned to a plane bending vibration of $\mathrm{C}-\mathrm{H}$ (mode of $\mathrm{N}=\mathrm{Q}=\mathrm{N}, \quad \mathrm{Q}=\mathrm{N}^{+} \mathrm{H}-\mathrm{B}$, and $\mathrm{B}-\mathrm{N}^{+} \mathrm{H}-\mathrm{B}$ ), which is formed during protonation [26]. The bands appearing at $715 \mathrm{~cm}^{-1}$ are attributed to an aromatic $\mathrm{C}-\mathrm{H}$ out-of-plane bending vibration [27]. For $\mathrm{TiO}_{2}$ nanoparticle, the broad peak at $3,449 \mathrm{~cm}^{-1}$ corresponds to stretching motions of the surface hydroxyl or the adsorbed water and the peak at $1,634 \mathrm{~cm}^{-1}$ corresponds to vibration of $\mathrm{O}-\mathrm{H}$ bonds on the $\mathrm{TiO}_{2}$ nanoparticles surface. The broad band observed in the region $825 \mathrm{~cm}^{-1}$ corresponds to $\mathrm{Ti}-\mathrm{O}$ stretching peak [28].

The FTIR spectrum of the $\mathrm{PANI} / \mathrm{TiO}_{2}$ nanocomposites contains contributions from both $\mathrm{TiO}_{2}$ nanoparticle and polymers. However, some bands of doped PANI had shifted due to interactions with $\mathrm{TiO}_{2}$ nanoparticle. For example, the bands at $1,587 \mathrm{~cm}^{-1}, 1,541 \mathrm{~cm}^{-1}$, and $1,394 \mathrm{~cm}^{-1}$, corresponding to the stretching mode of $\mathrm{C}=\mathrm{N}, \mathrm{C}=\mathrm{C}$, and $\mathrm{C}-\mathrm{N}$, and $\mathrm{N}-\mathrm{H}$ stretching band at $3,450 \mathrm{~cm}^{-1}$ are shifted to lower wavenumbers. These changes suggested that $\mathrm{C}=\mathrm{N}, \mathrm{C}=\mathrm{C}, \mathrm{C}-\mathrm{N}$, and $\mathrm{N}-\mathrm{H}$ bands became stronger in $\mathrm{PANI} / \mathrm{TiO}_{2}$ nanocomposite [19]. The band around $865 \mathrm{~cm}^{-1}$ are due to the presence of $\mathrm{TiO}_{2}$ nanopowder.

In spectrum of $\mathrm{PPA} / \mathrm{TiO}_{2}$, a band at $3,207 \mathrm{~cm}^{-1}$ appears showing the presence of chelate compounds. The band at $1,450 \mathrm{~cm}^{-1}$ may be due to $-\mathrm{CH}_{3}$ group or due to aromaticity. Additional bands at 1248; 1173 and $1026 \mathrm{~cm}^{-1}$ could be assigned to vibrations of the $\mathrm{C}-\mathrm{O}-\mathrm{C}$ bonds of the ether group [29] and aromatic $\mathrm{C}-\mathrm{O}$; [30] respectively. The band at $872 \mathrm{~cm}^{-1}$ shows the presence of $\mathrm{TiO}_{2}$.

Close examination of the poly(PA-co-ANI)/TiO ${ }_{2}$, reveals that the polymer contains all the main characteristics of bands of PANI and of PPA, i.e., the bands at 1,571 and $1,503 \mathrm{~cm}^{-1}$ are the stretching mode of $\mathrm{C}=\mathrm{N}$ and $\mathrm{C}=\mathrm{C}$; the weak peak at $1450 \mathrm{~cm}^{-1}$ is attributed to the $\mathrm{C}-\mathrm{H}$ bond of $-\mathrm{OCH}_{3}$ bending vibration [27, 31]. These peaks when compared to that of pure PANI and PPA [245, [32]] are found to be shifted slightly due to strong attraction of $\mathrm{TiO}_{2}$ particle with copolymer. Similar observation has been reported by Lee et al. [33], and strong absorption around $865 \mathrm{~cm}^{-1}$ due to Ti-O stretching [23] is observed while this band is found to be weak in poly(PA-co-ANI)/ $/ \mathrm{TiO}_{2}$ nanocomposite due to the presence of $\mathrm{TiO}_{2}$ nanoparticule.

\section{Electrical Conductivity Characterization}

Table 2 shows the electrical conductivities of nanocomposites that are in the range of $0.08-0.91{\mathrm{~S} . \mathrm{cm}^{-1}}^{-}$. It can be observed that the electrical conductivity follows the tendency of the pure polymers. Then the composite with polyanilile has the higher conductivity and the lower conductivity is obtained with the PPA composite. In all the cases, the conductivity of the composites is lower than the pure polymers. Then, the reduction of conductivity in the nanocomposite samples can be explained by the interactions at the interface of polymers and $\mathrm{TiO}_{2}$ nanoparticles which probably led to the reduction in conjugation length of polymers [17, 18]. On the one hand, the presence of $\mathrm{TiO}_{2}$ nanoparticles hindered the transport of carriers between different molecular chains of polymer [18]. 
TABLE 2. The electrical conductivity values of $\mathrm{PPA} / \mathrm{TiO}_{2}$, poly $(\mathrm{PA}-\mathrm{co}-\mathrm{ANI}) / \mathrm{TiO}_{2}$ and $\mathrm{PANI} / \mathrm{TiO}_{2}$ nanocomposites and pure polymers.

\begin{tabular}{|c|c|c|c|c|c|c|}
\hline Samples & $\mathrm{PPA} / \mathrm{TiO}_{2}$ & Poly(PA-co-ANI) $/ \mathrm{TiO}_{2}$ & $\mathrm{PANI} / \mathrm{TiO}_{2}$ & PPA & $\operatorname{poly}(\mathrm{PA}-\mathrm{co}-\mathrm{ANI})$ & PANI \\
\hline Conductivity $\left(\mathrm{S} . \mathrm{cm}^{-1}\right)$ & 0.08 & 0.12 & 0.91 & 0.22 & 0.82 & 1.45 \\
\hline
\end{tabular}

\section{UV-Vis Spectroscopy}

Figure 4 shows the UV-Vis absorption spectra of PPA/ $\mathrm{TiO}_{2}$, poly(PA-co-ANI)/TiO ${ }_{2}$ and $\mathrm{PANI} / \mathrm{TiO}_{2}$ nanocomposites dissolved in N-methyl-2-pyrrolidone (NMP) solution. The three samples show two characteristic absorption peaks. The absorption band at $\sim 298-323 \mathrm{~nm}$ can be ascribed to $\pi-\pi^{*}$ transition of the benzenoid rings, whereas the band at $\sim 450-457 \mathrm{~nm}$ can be attributed to polaron- $\pi^{*}$ transition and $\pi$-polaron transition, respectively [34]. Therefore, it can be concluded from the UVVis absorption spectra of $\mathrm{PPA} / \mathrm{TiO}_{2}$ that the doped state can be enhanced with the incorporation of PA units in polymer chain, which may be resulted from which has strong electronic effect that can stabilize the doping state of polymer.

It is found that the poly(PA-co-ANI)/TiO ${ }_{2}$ exhibits lowest in these of composites, which implies the doping level of copolymer nanocomposite is lower than that of homopolymer nanocomposites.

This is in consistent with the results of FTIR spectra. When comparing the absorption spectra, a notable red shift of the bands are observed for poly(PA-co-ANI)/TiO ${ }_{2}$ nanocomposite as compared to homopolymer nanocomposites, and the red shift is larger for $\mathrm{PANI} / \mathrm{TiO}_{2}$ than PPA/ $\mathrm{TiO}_{2}$. This indicates a higher conjugation length appearing in copolymers nanocomposite. The effective conjugation length favors planar chain structures and steric factors that prevent to give twisted chains. Evidently, the steric hindrance connected with $-\mathrm{OCH}_{3}$ substituent results in twisting, thus lowering the conjugation length in PPA [4].

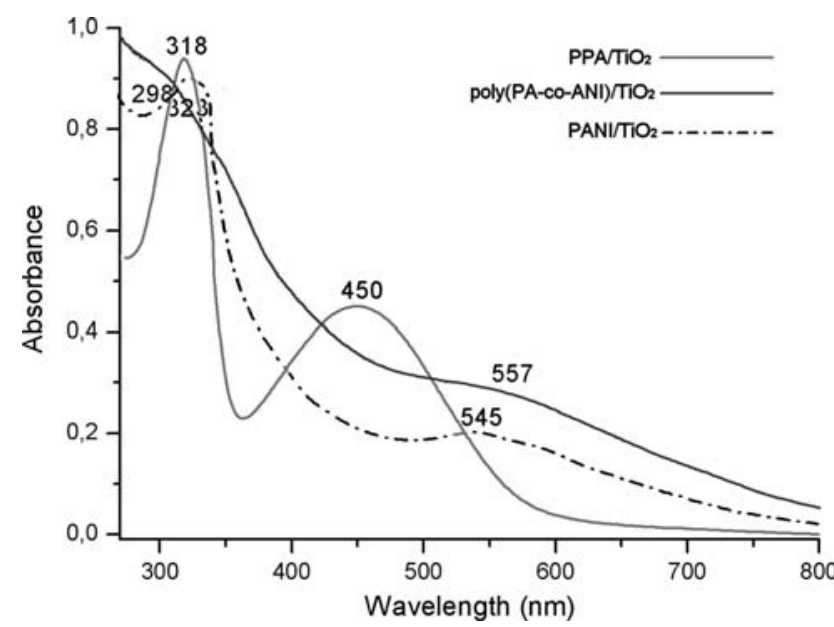

FIG. 4. UV-vis spectra of $\mathrm{PPA} / \mathrm{TiO}_{2}$, poly(PA-co-ANI)/TiO 2 , and $\mathrm{PANI} / \mathrm{TiO}_{2}$ nanocomposites. [Color figure can be viewed in the online issue, which is available at wileyonlinelibrary.com.]

\section{Thermogravimetric Analysis (TGA)}

TGA is one of the thermal analysis techniques used to quantify weight change and thermal decomposition of the sample. The TGA curves of pure $\mathrm{TiO}_{2}$ nanopowder only show a small $5.5 \%$ weight loss observed at $340^{\circ} \mathrm{C}$, and can be ascribed to the elimination of water and the partial dehydroxylation of the $\mathrm{TiO}_{2}$ nanopowder as shown in Fig. 5.

The thermal behavior of PPA pure is similar to that of PANI pure and exhibits a four-stage decomposition pattern. In the first stage, the weight loss starting practically from room temperature to $70^{\circ} \mathrm{C}$ is due to the loss of water molecules and moisture present in the polymer matrix. The second- and third-stage losses that occur from $70^{\circ} \mathrm{C}$ to $340^{\circ} \mathrm{C}$ are attributed to the loss of the dopant from the polymer chains. While the fourth stage loss from $350^{\circ} \mathrm{C}$ to $600^{\circ} \mathrm{C}$ is the result of the complete degradation and decomposition of the polymer backbone [35].

The PPA/TiO 2 , poly $(\mathrm{PA}-\mathrm{co}-\mathrm{ANI}) / \mathrm{TiO}_{2}$ and $\mathrm{PANI} / \mathrm{TiO}_{2}$ demonstrates that the thermo stability of nanocomposites depends on the polymer type used (structure of the polymers and the interaction between the two components) [36].

$\mathrm{PANI} / \mathrm{TiO}_{2}$ loses $12 \%$ of their weight at $340^{\circ} \mathrm{C}$, and lose $31.7 \%$ at $600^{\circ} \mathrm{C}$. In the case of poly(PA-co-ANI)/ $\mathrm{TiO}_{2}, 14 \%$ and $32.5 \%$ weight is lost at $340^{\circ} \mathrm{C}$ and $600^{\circ} \mathrm{C}$, respectively; these results indicating that the two nanocomposites have almost the same thermal stability. In case of $\mathrm{PPA} / \mathrm{TiO}_{2}$, the thermal stability reduce, while $16 \%$ weight is lost at $300^{\circ} \mathrm{C}$, and loses about $35 \%$ weight

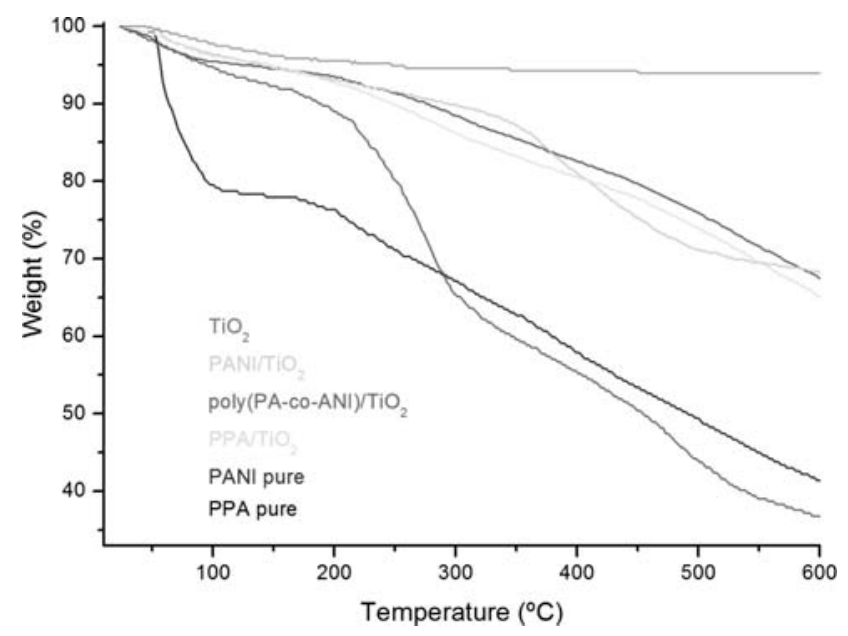

FIG. 5. Thermogravimetric analysis of $\mathrm{PPA} / \mathrm{TiO}_{2}$, poly(PA-co-ANI)/ $\mathrm{TiO}_{2}, \mathrm{PANI} / \mathrm{TiO}_{2}$ nanocomposites, pure PANI, pure PPA, and $\mathrm{TiO}_{2}$ nanoparticule obtained in nitrogen atmosphere at heating rate of $10^{\circ} \mathrm{C} \mathrm{min}^{-1}$. [Color figure can be viewed in the online issue, which is available at wileyonlinelibrary.com.] 


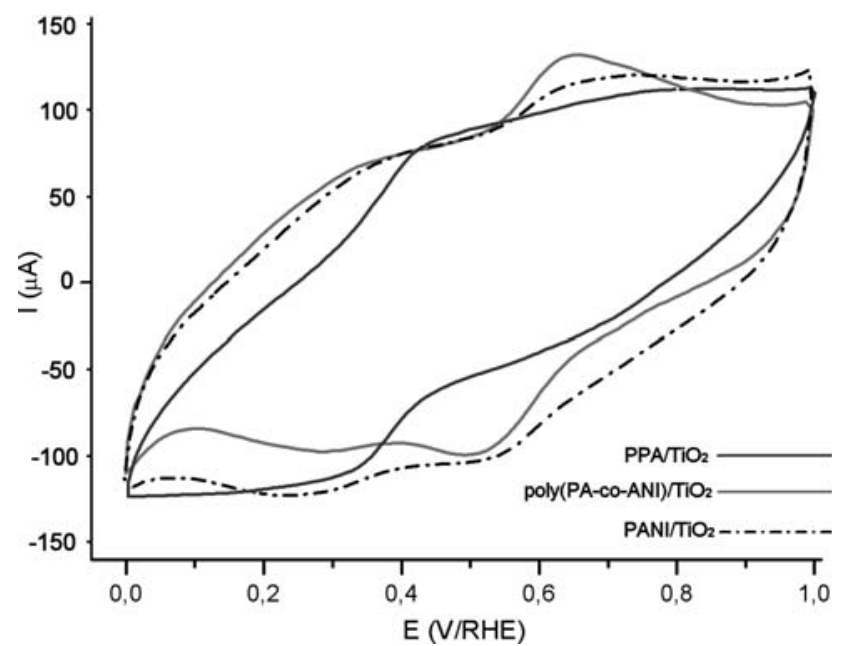

FIG. 6. Cyclic voltammograms recorded for a graphite carbon electrode covered by nanocomposites in $1 \mathrm{M} \mathrm{HClO}_{4}$ solution. Scan rate 50 $\mathrm{mV} \mathrm{s}^{-1}$. [Color figure can be viewed in the online issue, which is available at wileyonlinelibrary.com.] at $600^{\circ} \mathrm{C}$, which indicates that this material was less stable than the $\mathrm{PANI} / \mathrm{TiO}_{2}$ and poly $(\mathrm{PA}-\mathrm{co}-\mathrm{ANI}) / \mathrm{TiO}_{2}$.

\section{Electrochemical Properties}

Cyclic voltammetry experiments were performed to test the electroactivity of the polymer extracted from the nanocomposites. Figure 6 shows the steady voltammograms of polymers from $\mathrm{PPA} / \mathrm{TiO}_{2}$, poly(PA-co-ANI)/ $\mathrm{TiO}_{2}$ and $\mathrm{PANI} / \mathrm{TiO}_{2}$ samples, obtained in $1 \mathrm{M} \mathrm{HClO}_{4}$ solution at a scan rate of $50 \mathrm{mV} \mathrm{s}^{-1}$. In the case of $\mathrm{PANI} / \mathrm{TiO}_{2}$ nanocomposite, two overlapped redox processes are observed. The first one appears at $0.36 / 0.25 \mathrm{~V}$, which results in a potential peak separation $\left(\Delta E_{\mathrm{p}}\right)$ close to $110 \mathrm{mV}$; the second process is observed at $0.62 / 0.53 \mathrm{~V}$ and gives an $\Delta E_{\mathrm{p}}$ value of $90 \mathrm{mV}$. The first redox process is due to the oxidation of the benzenoid form of polyaniline and the second one to the oxidation of the quinoid form of polyaniline [37]. The voltammetric profiles for copolymer from poly(PA-co-ANI)/ $/ \mathrm{TiO}_{2}$ also show two
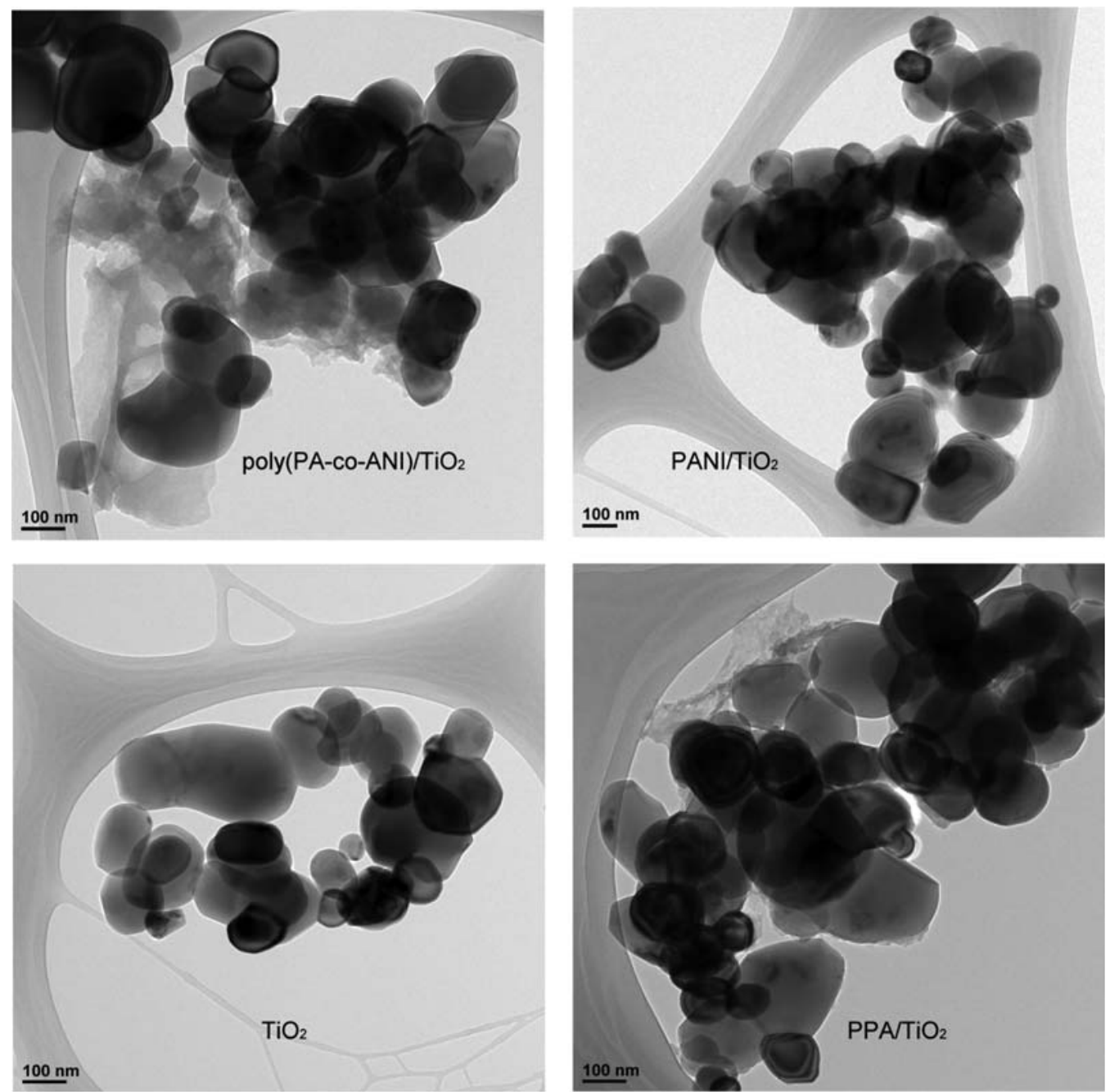

FIG. 7. TEM images of PPA/TiO 2 , poly $(\mathrm{PA}-\mathrm{co}-\mathrm{ANI}) / \mathrm{TiO}_{2}, \mathrm{PANI} / \mathrm{TiO} \mathrm{O}_{2}$ nanocomposites and $\mathrm{TiO}_{2}$ nanoparticles. 
redox process, the first centered at $0.34 / 0.29 \mathrm{~V}$ and gives a $\Delta E_{\mathrm{p}}$ value of $50 \mathrm{mV}$; the second process obtained at $0.64 / 0.54 \mathrm{~V}$ and gives a $\Delta E_{\mathrm{p}}$ value of $100 \mathrm{mV}$. The difference of the redox processes observed between these two cyclic voltammograms indicates that the structure of polymers are different, thereby confirming the existence of monomer PA in the copolymer structure. Contrary to what is observed for the $\mathrm{PPA} / \mathrm{TiO}_{2}$, the voltammetric curve displayed a unique redox process at $0.43 / 0.33 \mathrm{~V}$ with $\Delta E_{\mathrm{p}}$ value of $100 \mathrm{mV}$.

\section{Transmission Electron Micrographs (TEM)}

Figure 7 shows the TEM images of the nanocomposites $\left(\mathrm{PPA} / \mathrm{TiO}_{2}\right.$, poly(PA-co-ANI)/TiO 2 and $\left.\mathrm{PANI} / \mathrm{TiO}_{2}\right)$ and nanoparticle (pure $\mathrm{TiO}_{2}$ ). The TEM image indicates that some black streaks with various lengths distributed on polymers nanosheets, which are mixture of $\mathrm{TiO}_{2}$.

\section{CONCLUSIONS}

Polymer/ $/ \mathrm{TiO}_{2}$ nanocomposite samples were synthesized using chemical oxidation at room temperature using p-anisidine and/or aniline monomers and oxide titaniu$\mathrm{m}(\mathrm{IV})$ oxide in the presence of hydrochloric acid as a dopant with ammonium persulfate as an oxidant. The structural and absorption studies of polymer/ $/ \mathrm{TiO}_{2}$ support the efficient interaction of $\mathrm{TiO}_{2}$ nanoparticles. The shift and changes in the intensity of the peaks obtained from FTIR and XRD can be attributed to the substantive internalization on $\mathrm{TiO}_{2}$ nanoparticles. A polymer monolayer was formed on the $\mathrm{TiO}_{2}$ surface according to TEM measurements. The electrochemical behavior of the polymers extracted from the nanocomposites has been analyzed by cyclic voltammetry. The cyclic voltammograms show the typical response observed for these conducting polymer polymers with the presence of redox processes corresponding to the different oxidation/reduction states of the polymers. Then, the in situ polymerization on $\mathrm{TiO}_{2}$ nanoparticles produces electroactive polymers.

\section{REFERENCES}

1. H. Zhang, H. Yu, Y. Han, P. Liu, S. Zhang, P. Wang, Y. Cheng, and H. Zhao, Nano Res., 4, 938 (2011).

2. J.W. Lee, K.J. Hwang, W.G. Shim, K.H. Park, H.B. Gu, and K.H. Kwun, Kor. J. Chem. Eng., 24, 847 (2007).

3. A.I. Cardona, R. Candal, B. Sanchez, P. Avila, and M. Rebollar, Energy, 29, 845 (2004).

4. H. Kozuka, Y. Takahashi, G. Zhao, and T. Yoko, Thin Solid Films, 358, 172 (2000).

5. M. Zukalova, A. Zukal, L. Kavan, M.K. Nazeeruddin, P. Liska, and M. Gratzel, Nano Lett., 5, 1789 (2005).

6. B. O'Regan and M. Graetzel, Nature, 353, 737 (1991).

7. G.K. Mor, O.K. Varghese, M. Paulose, K. Shankar, and C.A. Grimes, Solar Energy Mater. Solar Cells, 90, 2011 (2006).
8. K.H. An, S.Y. Jeong, H.R. Hwang, and Y.H. Lee, $A d v$. Mater., 16, 1005 (2004).

9. D. Patil, P. Patil, Y.K. Seob, and Y.K. Hwang, Sens. Actuators $B, \mathbf{1 4 8}, 41$ (2010).

10. G. Neri, A. Bonavita, S. Galvagno, P. Siciliano, and S. Capone, Sens. Actuators B, 82, 40 (2002).

11. M. Porramezan and H. Eisazadeh, Compos. Part B, 42, 1980 (2011).

12. X.F. Yang, G.C. Wang, R.Y. Wang, and X.W. Li., Electrochim. Acta., 55, 5414 (2010).

13. L. Ai and J. Jiang, Curr. Appl. Phys., 10, 284 (2010).

14. D. Patil, Y.K. Seo, Y.K. Hwang, J.S. Chang, and P. Patil, Sens Actuators B, 128, 374 (2008).

15. J. Jiang, L.H. Ai, and A.H. Liu, Synthetic Metals, 160, 333 (2010).

16. N.A. Mansour, M.G. Mohamed, M.Y. Abed, and A.M. Mazrouaa, High Perform. Polym., 24, 625 (2012).

17. L.H. Mahajan and S.T. Mhaske, Mater. Lett., 68, 183 (2012).

18. C. Bian and G. Xue, Mater. Lett., 61, 1299 (2007).

19. R.M. Khafagy, J. Alloys Compounds, 509, 9849 (2011).

20. J. Jiang, L. Li, and F. Xu, Mater. Sci. Eng. A, 456, 300 (2007).

21. I. Toumi, A. Benyoucef, A. Yahiaoui, C. Quijada, and E. Morallon, J. Alloys Compounds, 551, 212 (2013).

22. M. Radoičića, Z. Šaponjića, I.A. Jankovića, G. ĆirićMarjanovićb, S.P. Ahrenkielc, and M.I. Čomor, Appl. Catalysis B: Environ., 136, 133 (2013).

23. Z. Zhao, Y. Zhou, W. Wan, F. Wang, Q. Zhang, and Y. Lin, Mater. Lett., 130, 150 (2014).

24. S. Sathiyanarayanan, S. Syed Azim, and G. Venkatachari, Synth. Metals, 157, 205 (2007).

25. H.P. Klug and L.E. Alexander. Wiley, New York (1954).

26. X. Li, G. Wang, X. Li, and D. Lu, Appl. Surf. Sci., 229, 395 (2004).

27. F. Xu, R. Jamal, A. Ubul, W. Shao, and T. Abdiryim, Fibers Polym., 14, 8 (2013).

28. S. Mallakpour and A. Barati, J. Polym. Res., 19, 1 (2012).

29. R.L. Pecsok, L.D. Shields, T. Cairns, and I.G. McWilliam, 2nd ed., Wiley, New York (1976).

30. R.M. Silverstein and G.C. Bassler, 2nd ed., Wiley, New York (1968).

31. P.A. Basnayaka, M.K. Ram, L. Stefanakos, and A. Kumar, Mater. Chem. Phys., 141, 263 (2013).

32. R.A. Salih, J. Mater. Environ. Sci., 3, 50 (2012).

33. J.C. Xu, W.M. Liu, and H.L. Li, Mater. Sci. Eng. C, 25, 444 (2005).

34. T. Abdiryim, R. Jamal, and I. Nurulla, J. Appl. Polym. Sci., 105, 576 (2007).

35. M.C. Gupta and S.S. Umare, Macromolecules, 25, 138 (1992).

36. S. Bitao, M. Shixiong, S. Shixiong, T. Yongchun, and B. Jie, Front Chem. China, 2, 123 (2007).

37. A. Kellenberger, N. Plesu, M.T.L. Mihali, and N. Vaszilcsin, Polymer, 54, 3166 (2013). 
[AQ1]: Please confirm that all author names are OK and are set with first name first, surname last and spelled out in full.

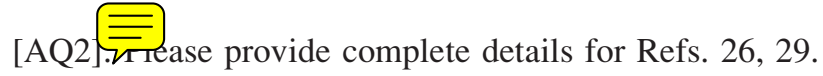

[AQ3]: Please confirm whether the color figures should be reproduced in color or black and white in the print version. If the color figures must be reproduced in color in the print version, please fill the color charge form immediately and return to Production Editor. Or else, the color figures for your article will appear in color in the online version only.

AQ4: Please confirm that given names (red) and surnames/family names (green) have been identified correctly.

Please confirm that the funding sponsor list below was correctly extracted from your article: that it includes all funders and that the text has been matched to the correct FundRef Registry organization names. If a name was not found in the FundRef registry, it may be not the canonical name form or it may be a program name rather than an organization name or it may be an organization not yet included in FundRef Registry. If you know of another name form or a parent organization name for a not found item on this list below, please share that information.

\begin{tabular}{|l|l|l|l|}
\hline FundRef name & $\begin{array}{l}\text { FundRef Organization } \\
\text { Name (Country) }\end{array}$ & FundRef DOI & Grant IDs \\
\hline $\begin{array}{l}\text { National Assessment and } \\
\text { Planning Committee of the } \\
\text { University Research } \\
\text { (CNEPRU) }\end{array}$ & $\begin{array}{l}\text { National Helanning Conmmission of } \\
\text { Planily } \\
\text { the People's Republic of } \\
\text { China }\end{array}$ & $10.13039 / 501100004572$ & E-03720130015 \\
\hline MINECO & $\begin{array}{l}\text { Ministerio de Economía y } \\
\text { Competitividad }\end{array}$ & $10.13039 / 501100003329$ & MAT2013-42007-P \\
\hline Generalitat Valenciana & Generalitat Valenciana & $10.13039 / 501100003359$ & PROMETEO2013/038 \\
\hline $\begin{array}{l}\text { Directorate General of Sci- } \\
\text { entific Research and Tech- } \\
\text { nological Development } \\
\text { (DGRSDT) of Algeria }\end{array}$ & $\begin{array}{l}\text { Direction Générale de la } \\
\text { Recherche Scientifique et } \\
\text { du Développement } \\
\text { Technologique }\end{array}$ & $10.13039 / 501100005307$ & \\
\hline
\end{tabular}

